\title{
DESIGN, DEVELOPMENT AND PERFORMANCE EVALUATION OF SOLAR POWER ASSISTED TRICYCLE
}

\author{
Rajendra Beedu ${ }^{1}$ \\ ${ }^{\text {I}}$ Professor, Mechanical \& Mfg Engineering, Manipal Institute of Technology, Manipal, India
}

\begin{abstract}
Solar energy is the only source of renewable energy which can be a feasible alternative for fossil fuels. In this work, a solar powered cycle is fabricated by modifying a all geared bicycle. The discussion covers the design, assembly and performance evaluation of the tricycle. The selection of electric motor, solar charger and panels are dealt with. The paper highlights the advantages of dual mode of charging and economic feasibility of the tricycle.
\end{abstract}

Keywords: Eco-friendly, solar charger, Brushless Motor

\section{INTRODUCTION}

The fast depletion of fossil fuels due to exponential increase in demand and global warming due to the emission of $\mathrm{CO}_{2}$ made engineers and scientists to look for an alternative source of energy which is renewable, eco-friendly, affordable and available. Among the renewable sources like wind, tidal, geothermal and solar energy, solar power is promising in nations like India which is in the tropical region. India spends large amount of foreign exchange to import crude oil . With the use of solar power assisted vehicles, the dependency on the import of crude oil can be reduced and reasonable amount of foreign exchange can be saved.

The $\mathrm{CO}_{2}$ emission is increased from 12 billion metric tonnes to 32 billon metric tonnes from 1965 to $2010 \mathrm{~A}$. D[1]. The rate of emission of $\mathrm{CO}_{2}$ is an indication of global warming. India has abundant solar power, $2015 \mathrm{kWh} / \mathrm{m}^{2}[2]$. Many researchers have designed solar assisted racing cars [3]. These cars are unaffordable for a common man.

Cycle Rickshaws are one of the mode of transportation in some places. Mounting the solar panel to these rickshaws will assist the cyclist in riding the tricycle , reduce fatigue, increase speed and also gives shade. The major problem in a tricycle is that in climbing slopes. By modifying a tricycle into motor assisted tricycle the cycle can make use of both manual effort and motor power and climbing the slope upto $15^{0}$ is comfortable for the rider. Even such a design has the difficulty in charging the battery especially in rural areas. If the battery which supplies power to the motor is charged in dual mode either by electric supply or using solar panel the problem of charging the battery is solved. Hence a solar powered tricycle provides a feasible alternative for local trip. The main advantages of the solar powered tricycle are low cost and pollution free ride.

Many researchers and scientists have struggled to explore the use of solar power in transport vehicle. The major drawback of solar panel is its low efficiency and high cost.
As a result, it is feasible to develop solar power assisted transport system. Shirsendu Das and Amit Kumar (2015) in their paper "Concept of Electromagnetic Solar Based Power Drive for Automobile" [1] have discussed the environmental issues of conventional I C engine and highlighted the advantage of using solar power assisted vehicle. R.Arulbel Benela and . K. Jamuna (2015) in their paper "Design of Charging Unit for Electric Vehicles Using Solar Power" [2] have developed a simulated model for charging plug in electric vehicles from a common solar panels and discussed the feasibility of utilization of solar power.

Ranjeet Singh, Manoj Kumar Gaur, Chandra Shekhar Malvi (2012) in their paper "Study of Solar Energy Operated Hybrid Mild Cars; A Review" [3], discussed the current trends in the design hybrid cars (electrically or solar powered). Ajit B Bachche and N M Hanamapure, in their paper "Design and Development of Solar Assisted Bicycle" [4], have given the design and feasibility study of solar powered bicycle. V.Naveen Prabhu and N.Manigandan, in their paper " Design and Fabrication of Solar Transport Vehicle" [6] , have discussed the marketability of solar powered vehicles. Alisaa Kumari et.al.,in their paper, "Solar Powered Vehicle" [7], have highlighted the features of solar powered vehicle.

\subsection{Design}

The design involves the calculation of driving torque and power required for the tricycle, rating of motor, selection of motor, battery and number of solar panels.. A Hero DTB 6Speed Geared Cycle is the base model which is modified into a tricycle. The base model is shown in figure 1. 


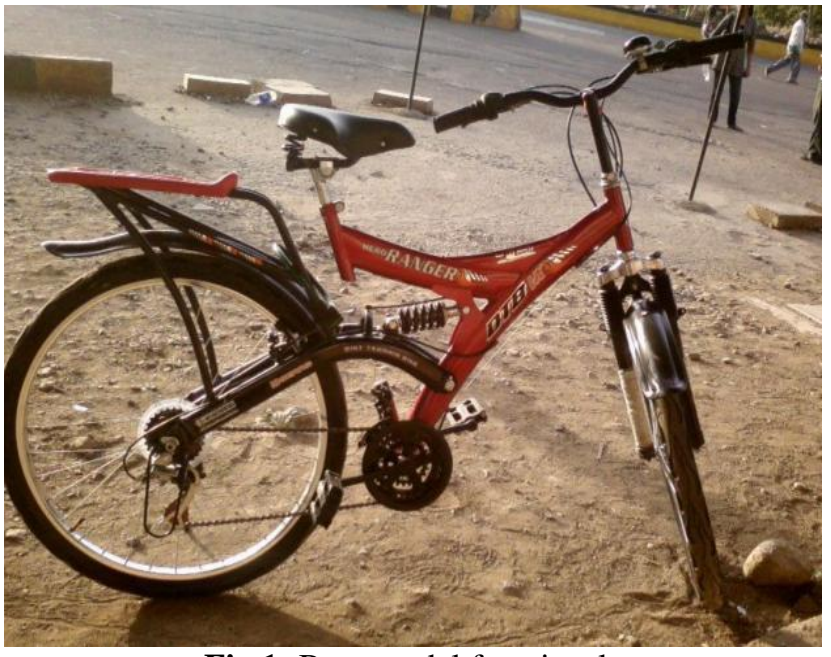

Fig 1: Base model for tricycle

\section{NOTATIONS [5]}

$\mathrm{d}=$ tricycle wheel rim diameter, $m$.

$\mathrm{r}=$ tricycle wheel rim radius, $m$.

$\omega=$ Angular velocity of tricycle shaft, $\mathrm{rad} / \mathrm{s}$.

$\mathrm{N}=$ Speed of tricycle wheel, $R P M$.

$\mathrm{v}=$ Speed of tricycle in $\mathrm{kmph}$

$\mathrm{N}_{1}=$ Normal reaction of the road on each tyre of the tricycle, $N$.

$\mu=$ Coefficient of friction $=0.3$.

$\mathrm{F}=$ Frictional force between tyre and road,$N$.

$\mathrm{T}=$ Torque developed on the shaft due to frictional force ,Nm.

$\mathrm{P}=$ Power required to ride the tricycle, $W$.

$\mathrm{t}=$ time needed to fully charge the battery with A-C Supply ,hours

\section{TECHNICAL DETAILS [5]}

\subsection{Cycle Dimensions [5]}

Cycle Rim Diameter $\mathrm{d}=50 \mathrm{~cm}=0.5 \mathrm{~m}$

Required Cycle Speed v $=10 \mathrm{kmph}$

Tricycle weight $=40 \mathrm{~kg}$

Rider Weight $=80 \mathrm{~kg}$

Total weight $\mathrm{W}=120 \mathrm{~kg}$.

\subsection{Power Calculations [5]}

Normal Reaction $\mathrm{N}_{1}$ on each tyre $=\mathrm{W} / 3$

Normal Reaction $\mathrm{N}_{1}=40 \mathrm{Kg}=392.40 \mathrm{~N}$

FRICTION FORCE ACTING ON EACH TYRE

$\mathrm{F}=\mu \mathrm{N}_{1}=117.72 \mathrm{~N}$

\subsection{Power Requirement [5]}

$\mathrm{T}=\mathrm{F} \times \mathrm{r}=29.43 \mathrm{Nm}$

\subsection{Speed Calculations [5]}

$\omega=\mathrm{v} \div \mathrm{r}, \omega=11.11 \mathrm{rad} / \mathrm{sec}$

$\mathrm{N}=(60 \times \omega) \div(2 \pi)$

$\mathrm{N}=106 \mathrm{rpm}$

\subsection{Power Requirements [5]}

$\mathrm{P}=(2 \pi \mathrm{N} \mathrm{T}) \div 60=326.56 \mathrm{~W}$

The power required for riding the tricycle is $326.56 \mathrm{~W}$. The solar power is used to assist the rider. Hence a motor of lesser power of $300 \mathrm{~W}$ is selected. The system can independently develop a speed of $7 \mathrm{kmph}$. [4]

\subsection{Battery Specifications: [5]}

Battery of voltage $24 \mathrm{~V}$ is selected and the current rating is calculated.

Power $=$ Voltage $\mathrm{x}$ Current

$\mathrm{P}=\mathrm{V} . \mathrm{I}$

$\mathrm{I}=\mathrm{P} / \mathrm{V}=12.5 \mathrm{Ah}$.

Hence according to the above calculations, to drive a motor of $300 \mathrm{~W}, 24 \mathrm{~V}$ capacity; 2 batteries of $12 \mathrm{~V}, 12 \mathrm{Ah}$ are connected in series. The total voltage supplied to the motor is $24 \mathrm{~V}$.

\section{ELECTRICAL CHARGING [5]}

Power Supplied to Battery during AC Charging: AC Adapter Specification: 12V, 12 A

The time required for completely charging the battery is calculated as follows

$$
\mathrm{P}=\mathrm{V} . \mathrm{I}=144 \mathrm{~W} .
$$

Therefore the time required to charge the battery completely is:

$$
\mathrm{t}=288 \div 144=2 \text { hours. }
$$

Hence, it is found that, the time required to charge the batteries completely is 2 hours.

\subsection{Solar Panel Selection}

Two solar panels of $20 \mathrm{~V}$ capacities is used to charge the battery. To develop a voltage of $288 \mathrm{~V}$, the time required is $288 / 40=7.2 \mathrm{hrs}$.

The solar cells are electrically connected as a module with a glass sheet at the top. It consists of photovoltaic cells which converts solar energy into electric current. If in the rainy season sun rays are blocked by the cloud from reaching the earth or during night, the voltage produced falls below $13.6 \mathrm{~V}$, the solar panel stops working. To ensure the availability of solar power throughout the day and to prevent the voltage drop during cloudy season, a solar charger is used. The solar charger is mounted with blockage diode to prevent the reverse flow of current The solar charger is shown in figure 2 [5]. 


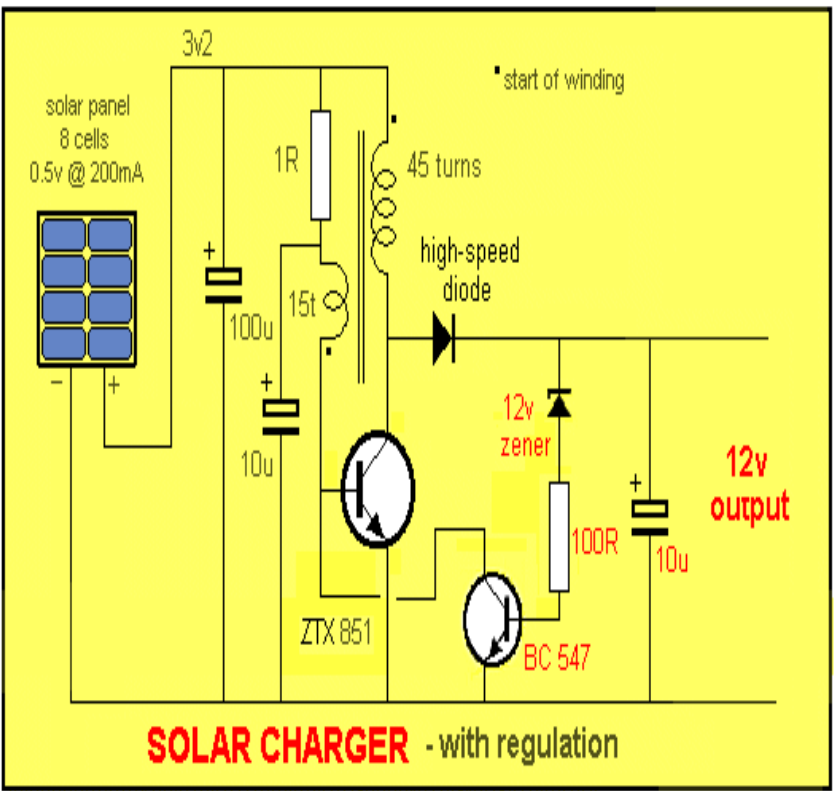

Fig 2: Solar charger [5].

Selection of Battery: The required voltage and the power in the battery is $24 \mathrm{~V}$ and $288 \mathrm{~W}$ respectively. The voltage, current and power rating of the battery are taken into account in deciding the type of the battery. Two Li- ion Battery with $12 \mathrm{~V}$ and 12 amp-hour rating are used .The block diagram indicating the assembly of various parts of solar power unit is shown in figure 3 .

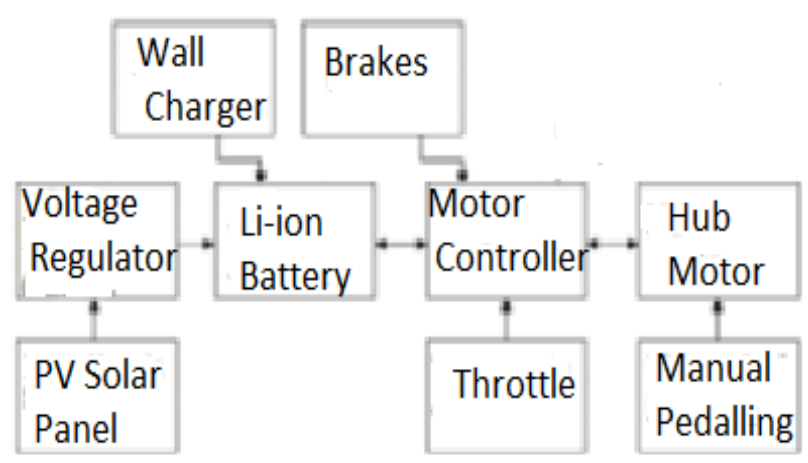

Fig 3: Block diagram of Solar Power Unit [4].

Selection of Motor: Selection of motor depends on the power requirement i.e $300 \mathrm{~W}$ and the mode of driving. Two types of motors are available, mechanically commuted D C motor and Brushless electronically commuted D C motor (BLDC motor). Among these two types, BLDC motor is preferred because it provides noiseless operation, more efficient, gives under voltage and over voltage protection and waterproof. The BLDC motor is shown in figure 4.

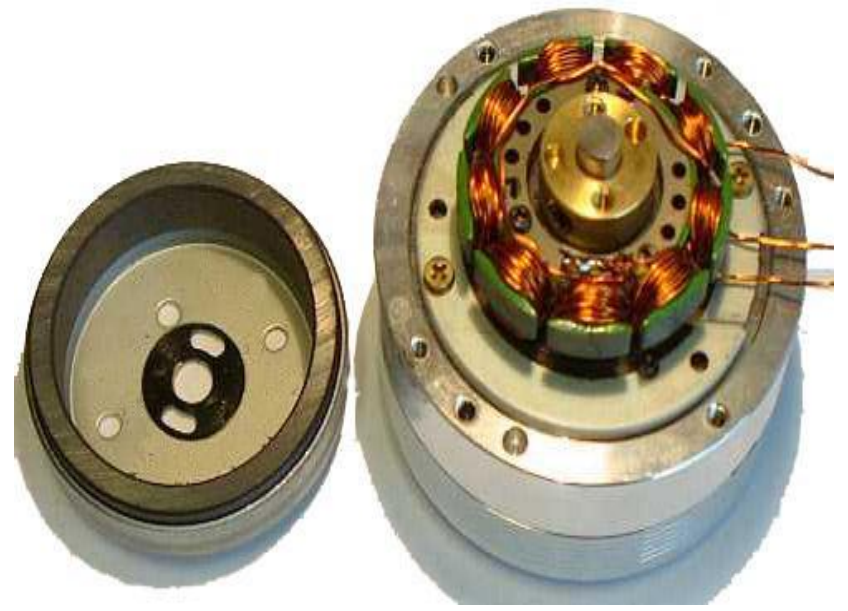

Fig 4: Brushless D C Motor[5].

\section{SPEED CONTROLLER}

A speed controller or electrical signal accelerator (Figure 6) is used to control the speed of the BLDC motor. It converts $\mathrm{DC}$ voltage into $\mathrm{AC}$ voltage with variable amplitude and frequency thereby regulating the speed of the hub motor. It works on the principle of Hall affect generator. The circuit diagram of speed controller is shown in figure 5.signals based on the rotation of the actuator.

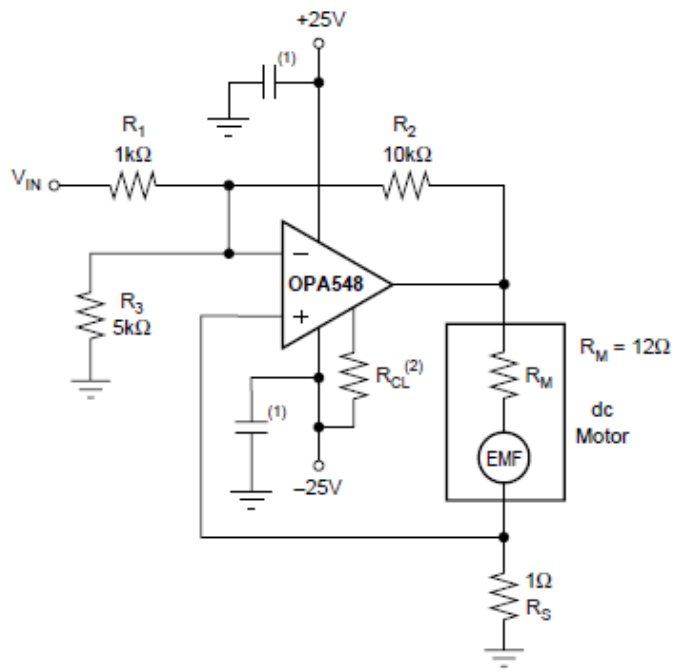

Fig 5 Speed Controller [4]

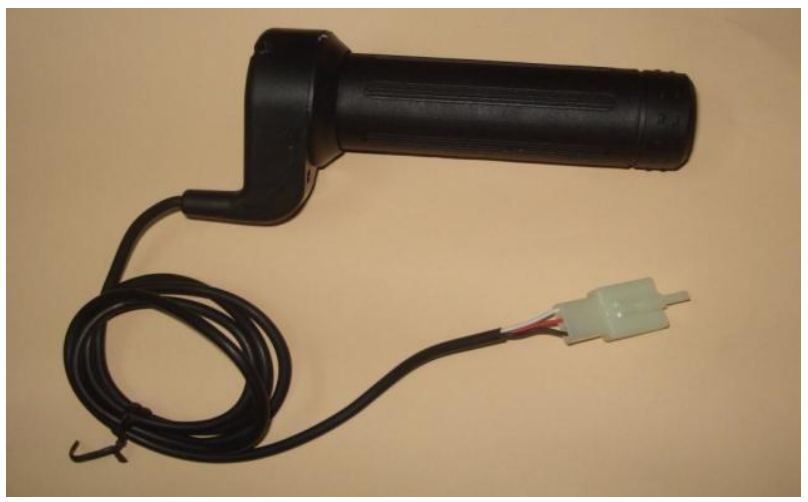

Fig 6: An Electric Throttle/Accelerator [5] 


\subsection{Fabrication}

The base model is first converted into a tricycle by replacing the rear wheel from a shaft carrying two wheels. A metallic stand is fixed to the carrier of the tricycle. The shaft of the front wheel carries the hub motor. Sufficient care is taken in mounting the hub motor to the shaft of the front wheel. The battery casing with two Li-ion batteries and regulator is mounted below the carrier. Proper wire connection is made from battery to motor to supply the current. Two solar panels are fixed to the stand. A solar charge controller is placed below the solar panels. The battery box contains has jacks for charging from solar panel or alternative current.

Thus the tricycle is made to operate in dual mode, either with solar power (as shown in figure 7) or with electrical source. The speed controller mounted in the handle cuts off the power supply to the motor and stops it. The same brake stops the cycle with conventional friction brake. The braking system stops motor as well as tricycle simultaneously [5]. The final assembly is shown in figure 8 .

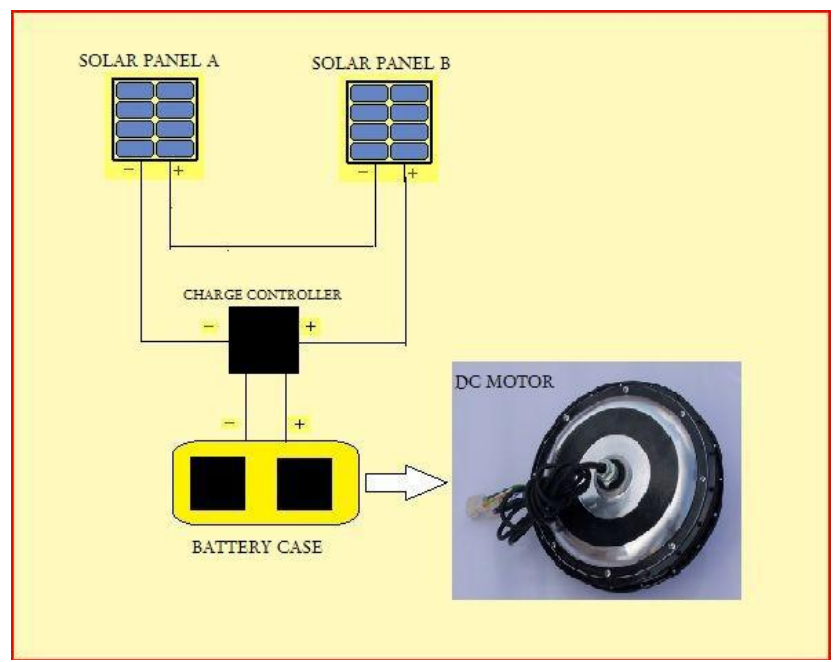

Fig 7: Circuit for Solar Panel[5]

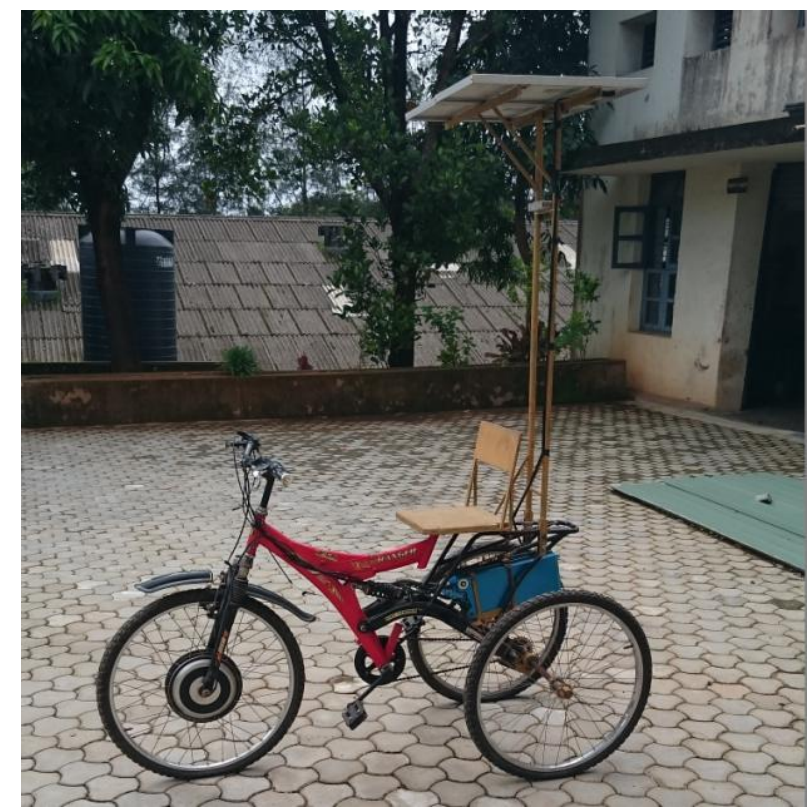

Fig 8 Solar Powered Tricycle

\section{RESULTS AND DISCUSSION}

The following results are obtained by testing the tricycle

1. Solar panels of $20 \%$ efficiency takes the charging time from 7.2 hrs whereas that with $35 \%$ efficiency takes 5 hours only.

2. The total charging time with electrical source 2.4 hrs

3. Total discharge period 1 hour

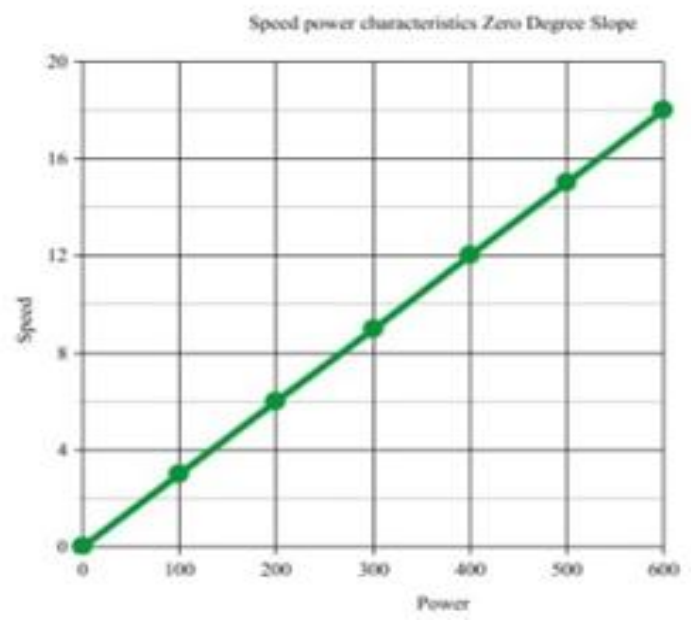

Fig 9: Speed of tricycle at zero slope

4. The maximum speed on plain flat road with zero slope without pedalling is $9 \mathrm{kmph}$.(figure 9)

5. The maximum speed on plain flat road with $7.5^{\circ}$ slope without pedalling is $7 \mathrm{kmph}$.(figure 10) and with $15^{\circ}$ slope is $5 \mathrm{kmph}$ respectively.(figure 11 ).

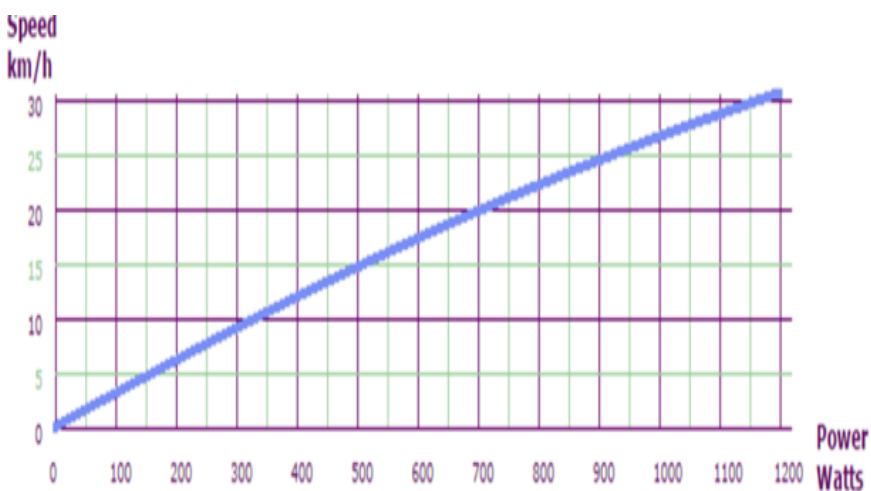

Fig 10 Speed of tricycle at $7.5^{\circ}$ slope[8]

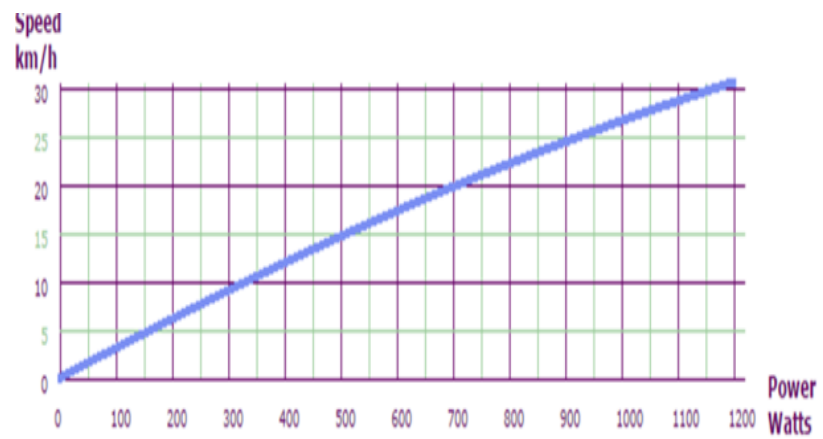

Fig 11 Speed of tricycle at $15^{\circ}$ slope [8] 
6. Once fully charged the tricycle can travel a distance of $19 \mathrm{~km}$ in one hour (with pedaling)

\subsection{Cost Analysis}

Table 1 Cost Analysis

\begin{tabular}{|l|l|l|l|}
\hline PART & $\begin{array}{l}\text { UNIT } \\
\text { COST (Rs) }\end{array}$ & $\begin{array}{l}\text { NUMB } \\
\text { ER }\end{array}$ & $\begin{array}{l}\text { COST(R } \\
\text { s) }\end{array}$ \\
\hline BLDC motor & 4000 & 1 & 4000 \\
\hline $\begin{array}{l}\text { li-ion } \\
\text { batteries- 12v, } \\
\text { 12Ah }\end{array}$ & 1900 & 2 & 3800 \\
\hline $\begin{array}{l}\text { Battery box } \\
\text { with AC } \\
\text { charger }\end{array}$ & 600 & 1 & 600 \\
\hline Bicycle panels- & 1500 & 1 & 4500 \\
\hline $\begin{array}{l}\text { Electrical } \\
\text { wiring }\end{array}$ & 500 & 1 & 500 \\
\hline Assembly & 1000 & 1 & 1000 \\
\hline $\begin{array}{l}\text { Solar } \\
\text { 20w }\end{array}$ & & 2000 \\
\hline $\begin{array}{l}\text { TOTAL } \\
\text { COST(INR) }\end{array}$ & 17,400 \\
\hline
\end{tabular}

The total cost of fabrication is Rs 17400. (table1) On batch production, the unit cost can be reduced.

\section{CONCLUSION}

The results reveal that a solar powered tricycle is a feasible alternative for local trip. The following conclusions are drawn from the results.

1. The solar powered tricycle can be a replacement for auto rickshaw.

2. The solar power assisted tricycle will work with a reasonable speed with less fatigue to the rider.

3. The tricycle is more stable compared to a bicycle.

4. The solar panel mounted above provides shade as well as power.

5. For higher power, motor of higher capacity can be used.

6. The parking place for solar powered vehicle does not require a shed.

7. A parking shed with a roof made up solar panels and charging units can be a common utility for owners of solar powered tricycle. Such a system is called plug in electrical vehicle.

8. The ride is noise free, eco-friendly and cheaper than e bike or motor cycle.

9. The battery can be charged even during riding the tricycle. This ensures continuous energy input to the tricycle without any additional cost.

\section{REFERENCES}

[1] Shirsendu Das and Amit Kumar (2015) "Concept of Electromagnetic Solar Based Power Drive for Automobile" International Journal of Advanced Science and Technology,Vol. 76, page 21-28
[2] R.Arulbel Benela and . K. Jamuna (2015)“Design of Charging Unit for Electric Vehicles Using Solar Power"

[3] Ranjeet Singh, Manoj Kumar Gaur, Chandra Shekhar Malvi (2012)"Study of Solar Energy Operated Hybrid Mild Cars; A Review”, International Journal of Scientific Engineering and Technology Vol 1, Issue 4, page 139-148, (ISSN : 2277-1581)

[4] Ajit B. Bachche, ,N. S. Hanamapure,(2012), "Design and Development of solar assisted Bicycle" International Journal of Engineering and Innovative Technology (IJEIT) Volume 2, Issue 6, December 2012

[5] Rajendra Beedu et al.(2014) "Design, fabrication and performance analysis of solar power bicycle" International Journal of Renewable Energy and Environmental Engineering ISSN 2348-0157, Vol. 02, No. 03, July 2014

[6] V.Naveen Prabhu and N.Manigandan “ Design and Fabrication of Solar Transport Vehicle" IOSR Journal of Mechanical and Civil Engineering (IOSRJMCE) e-ISSN: 2278-1684, p-ISSN: 2320-334X

[7] Alisaa Kumari, Ankita Ranjan,, Shivangi Srivastava. (2014) "Solar Powered Vehicle" International Journal of Electronics, Electrical and Computational System IJEECS ISSN 2348-117X Volume 3, Issue 3 May 20148 www.kreuzotter.de. 